\title{
Osteopathic Manual Treatment for Pain Severity, Functional Improvement, and Return to Work in Patients With Chronic Pain
}

Yasir Rehman, MD, MSc, PhD (C); Hannah Ferguson, M.OMSc, BSc; Adelina Bozek, MD; Joshua Blair, M.OMSc, BSc; Ashley Allison, BA; Robert Johnston, M.OMSc

From the Canadian Academy of Osteopathy (CAO) in Hamilton, Ontario, Canada (Drs Rehman, Ferguson, Bozek, Blair, Allison, and Johnston); and the Health Research Methodology, Department of Health Research Methods, Evidence and Impact (HEI) and the Michael G. DeGroote Institute for Pain Research and Care (IPRC) at McMaster University, Hamilton, Ontario, Canada (Dr. Rehman). Financial Disclosures: None reported.

Support: Dr. Rehman was supported by the Canadian Academy of Osteopathy

Research Initiatives Grant. The funder had no input in the design, data collection, data analysis, or interpretation of data; writing of the manuscript; or the decision to submit the manuscript for publication.

Address correspondence to Yasir Rehman, MD, MSc, PhD,

Canadian Academy of Osteopathy (CAO), 66 Ottawa Street North, Hamilton, Ontario, Canada, L8H 3 Z1.

Email: yasirrehman@ canadianosteopathy.ca

Submitted January 30, 2020; revision received July 4, 2020; accepted July 10,2020 .
Context: Chronic non-cancer pain (CNCP) is associated with disability, poor quality of life (QOL), and failure to return to work (RTW). Osteopathic manipulative treatment (OMT) or osteopathic manual therapy (OMTh) are increasingly offered to patients with $\mathrm{CNCP}$; however, the existing systematic reviews and meta-analyses in the literature that explore the effectiveness of OMTh have major limitations.

Objective: To systematically evaluate the quality of evidence documenting the effectiveness of OMTh for patients with CNCP using the Grading of Recommendations Assessment, Development, and Evaluation (GRADE) approach, and to evaluate the efficacy of OMTh in patients with CNCP through a meta-analysis of pooled data from previous studies.

Methods: We searched online the databases Ovid, MEDLINE, Embase, OSTMED.DR, EMCare, Allied and Complementary Medicine Database (AMED), Physiotherapy Evidence Database (PEDro), and Cochrane Central Register of Controlled Trials (CENTRAL), as well as the bibliographic references of previous systematic review articles evaluating OMTh for pain severity, disability, QOL, or RTW outcomes. Eligibility included randomized controlled trials methodology, CNCP patients 18 years or older, use of previously validated assessment tools, use of OMTh as an active or combination intervention, and presence of a control or comparison group. We pooled studies based on the homogeneity between OMT comparator treatment and outcomes. Risk of bias was assessed with the Cochrane risk of bias tool and the quality of evidence was determined with GRADE.

Results: Sixteen randomized controlled trials ( $\mathrm{n}=1158$ patients) were eligible for data extraction. Moderate quality evidence showed that OMTh vs. standard care was significantly associated with a reduction in pain [standardized mean difference $(95 \% \mathrm{CI})=[-.37(-.58$, $-.17)]$ and disability $[-.28(-.46,-.10)]$, as well as improved QOL $[.67(.29,1.05)]$. Moderate quality evidence showed that OMTh plus exercise vs. exercise only was significantly associated with reduction in pain severity $[-1.25(-1.67,-.83)]$ and disability $[-1.15(-1.57,-.74)]$. Moderate quality evidence showed that using visceral OMTh vs. general OMTh was significantly associated with reduction in pain severity $[-.74(-1.09$, $-.39)]$ and disability $[-.52(-.91,-.13)]$. In comparison to physiotherapy, gabapentin, and OMTh plus gabapentin, OMTh did not show any significant effect for any of the outcomes. OMTh vs. standard care did not show significant improvement in RTW at 12 weeks, although the effect was significant at 8 weeks after OMTh.

Conclusion: Moderate quality evidence suggests that OMTh is effective for CNCP patients. There was a significant association between visceral OMTh and reduced pain severity and disability. More robust, high-quality randomized controlled trials with larger sample sizes are required to further explore the effectiveness of the OMTh in the management of CNCP.

J Am Osteopath Assoc. 2020;120(12):888-906. Published online September 17, 2020. doi:10.7556/jaoa.2020.128

Keywords: chronic pain, disability, OMT, osteopathic manipulative treatment, quality of life 


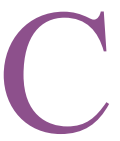

hronic noncancer pain (CNCP) affects approximately $19 \%$ of the general population $^{1-3}$ and includes a range of conditions that involve mechanical (eg, low back pain, osteoarthritis) and neuropathic (eg, fibromyalgia) disorders. CNCP interferes with activities of daily living, contributes to psychologic distress, and is associated with disability and work loss, ${ }^{2-5}$ causing substantial socioeconomic impact. ${ }^{6-8} \mathrm{CNCP}$ is also among the most common reasons for patients to consult general practitioners and specialist pain clinics. ${ }^{5,6}$ Management of CNCP is multi-disciplinary: combination treatments are reported to provide better pain relief and functional outcomes. ${ }^{9,10}$ Depending on the underlying cause, treatments for CNCP include pharmacologic intervention, psychotherapy, and physical treatments such as physiotherapy, chiropractic treatments, massage therapy, and osteopathic manipulative treatment (OMT) or osteopathic manual therapy (OMTh). ${ }^{10-12}$ Although the same principles are followed in the manual treatment approach, OMT is performed by physicians, whereas OMTh is performed by nonphysicians.

OMTh is increasingly employed to manage $\mathrm{CNCP}^{13,14}$ and, like other manual therapies, is known to alter biomechanical, neurophysiologic, and various other patient-related factors through anatomic and physiologic connections to the autonomic nervous system. ${ }^{15-18}$ OMTh requires a comprehensive understanding of anatomy and physiology and, based on osteopathic principles, uses that knowledge to mobilize and influence the patient's body. The 4 main principles of osteopathy ${ }^{19-21}$ are that the body is a unit and the person is a unit of body, mind, and spirit; the body is capable of selfregulation, self-healing, and health maintenance; structure and function are reciprocally interrelated; and rational treatment is based on an understanding of the basic principles of body unity, self-regulation, and the interrelationship of structure and function.

Although OMTh is increasingly offered to patients to help manage CNCP, it is still widely underused, and research into its benefits remains in its infancy. ${ }^{22-24}$ Previous systematic reviews and meta-analyses exploring the effectiveness of OMTh have had a variety of limitations such as language restriction, ${ }^{25}$ narrow search strategies, ${ }^{25}$ inclusion criteria not being restricted to randomized controlled trials (RCTs) ${ }^{26}$ or to OMTh topics, ${ }^{26,27}$ inclusion of studies with both acute and chronic pain, ${ }^{28-30}$ or inclusion of duplicate studies (such as substudies of larger trials). ${ }^{26}$ Given these limitations, interpreting the results of reviews and meta-analyses in the current literature and drawing conclusions about the effectiveness of OMTh can be challenging. Therefore, larger, high-quality data exploring the effectiveness of OMTh in the management of CNCP is sorely needed. Our goal was to conduct a systematic review and meta-analysis to explore the effectiveness of OMTh in $\mathrm{CNCP}$ and its effect on pain reduction, functional impairment, quality of life (QOL), and return to work (RTW). We also evaluated the quality of evidence in a thorough and consistent manner using the Grading of Recommendations Assessment, Development, and Evaluation (GRADE) approach. ${ }^{31,32}$

\section{Methods}

We conducted our meta-analysis according to Preferred Reporting Items for Systematic Reviews and Meta-Analyses (PRISMA) guidelines. ${ }^{33}$ The study protocol was registered with Prospero (Registration \#CRD42019125659).

The keywords for our searches were developed using the MeSH word analyzer (http://MeSH.med.yale.edu/). Searches were conducted starting in July 2018 and were updated in July 2019. We developed a broad search strategy using Ovid to search MEDLINE, Embase, OSTMED.DR, EMCare, Allied and Complementary Medicine Database (AMED), Physiotherapy Evidence Database (PEDro), and Cochrane Central Register of Controlled Trials (CENTRAL) databases. The bibliographic references of previous systematic reviews ${ }^{23-29}$ were also searched for eligible trials. The Ovid MEDLINE literature search strategy is provided in the eAppendix. Our eligibility criteria included randomized controlled trials 
(RCTs) that had enrolled CNCP patients 18 years of age or older, employed OMTh as an active or combination intervention, and compared OMTh to any other intervention or control. Eligible trials explored the effectiveness of OMTh on pain severity, disability, QOL, or RTW outcomes and were reported with previously validated tools. We excluded RCTs that enrolled $<10$ participants per arm at baseline or if the authors reported a composite score. Studies with a focus on cancerous pain, pain developed during pregnancy, headaches, pain due to gynecologic abnormalities, purely irritable bowel syndrome (IBS), or other visceral pain such as prostatitis were also excluded. We excluded crossover trials because of the possibility of carry-over effect and because methodologic challenges limit their applicability. ${ }^{34,35}$ Because OMTh is governed by a set of principles and uses a combination of methods to treat the body, ${ }^{30}$ we excluded studies that were specifically investigating a single technique without employing additional use of general OMTh. An amendment in our original Prospero protocol was made because we initially excluded pilot trials but found we did not have enough eligible studies and therefore broadened our inclusion criteria to include pilot trials.

\section{Data Collection and Analysis Plan}

Title and abstract, full text screening, data abstraction, and risk of bias (ROB) were compiled in duplicate and independently by a team of reviewers (Y.R., H.F., J.B., A.B., A.A.). We extracted information related to the trial design, patient demographics, interventions, outcomes, and ROB. When possible, we pooled studies according to the type of OMTh and comparator for each outcome. OMTh is applied according to an individual's condition and at the discretion of the examiner with variations; therefore, for pooling purposes we considered relative similarities between OMTh, treatment comparators, and outcomes across studies. ${ }^{35,36} \mathrm{We}$ reported results with standardized mean difference (SMD) with a $95 \%$ confidence interval (CI) interval. Albers et $\mathrm{al}^{37}$ and Licciardone et $\mathrm{al}^{38}$ were 3 -arm studies and, based on the similarities between the
OMTh applied and comparators, respectively, we merged the 2 arms. If we had 2 studies in the pooled analysis, we reported results with fixed effect model (FEM); if we had more than 2 studies in the pooled analysis, we reported results with random effect model (REM). For FEM, we also checked with REM for change in variability. We analyzed data with change scores, but in cases where change scores were not reported, we pooled with the final score according to Cochrane's criteria. ${ }^{35}$ If quantitative pooling was not possible, we reported outcomes descriptively.

\section{Quality of Evidence}

The quality of evidence was assessed using GRADE, ${ }^{31,32}$ which consists of 5 components: ROB, inconsistency, imprecision, publication bias, and indirectness.

Risk of bias: $\mathrm{ROB}$ was analyzed using a modified Cochrane ROB tool on the following components: random sequence generation, allocation concealment, blinding of participants, healthcare provider, outcome assessors, and dropout rates. ${ }^{35}$

Heterogeneity (inconsistency): Heterogeneity of the pooled studies was determined by visual inspection of forest plots and using the $\mathrm{I}^{2}$ statistic. For heterogeneity, we used a cutoff of $60 \%$ or if on visual inspection of the forest plot there was inconsistency in the effect estimates of individual studies. ${ }^{35}$

Publication bias: We did not have 10 or more studies in any pooled analysis and therefore could not assess publication bias in the pooled analysis.

Indirectness and inconsistency: The clinical characteristics of the participants and width of the confidence interval, respectively, were assessed for indirectness and inconsistency.

\section{Sensitivity and Subgroup Analysis}

We did not have enough studies to perform subgroup analysis according to the a priori specified in our Prospero protocol. We pooled studies comparing the effectiveness of OMTh against sham and OMTh against standard care (SC). Our rationale was based on 
the fact that studies with sham comparison allowed patients to continue usual treatment; therefore, we explored subgroup analysis to assess whether our rationale to pool studies with sham treatment and SC was justifiable. We also performed a sensitivity analysis to compare to previous systematic reviews by pooling studies according to low back pain (LBP) only, while ignoring the differences in control treatments/ comparators.

The statistical analysis was performed with Review Manager 5.3 (Review Manager [RevMan] version 5.3. Copenhagen: The Nordic Cochrane Centre, The Cochrane Collaboration, 2014).

\section{Results}

Our searches from all databases yielded 2956 studies for screening (Figure 1), out of which 16 studies were eligible for data extraction. A summary of the included studies is given in Table $\mathbf{1}$.

The collective sample size from all eligible studies was 1158 . The median age of the eligible population was 43.3 years, with a range of 23 to 78 years. Chronic LBP was the most prevalent pain type among the included studies. ${ }^{39-45}$ Three studies explored the effectiveness of OMTh in the treatment of neck pain, $39,40,46$ and other studies explored the effectiveness of OMTh in knee arthritis, ${ }^{41}$ shoulder pain, ${ }^{42}$ temporomandibular
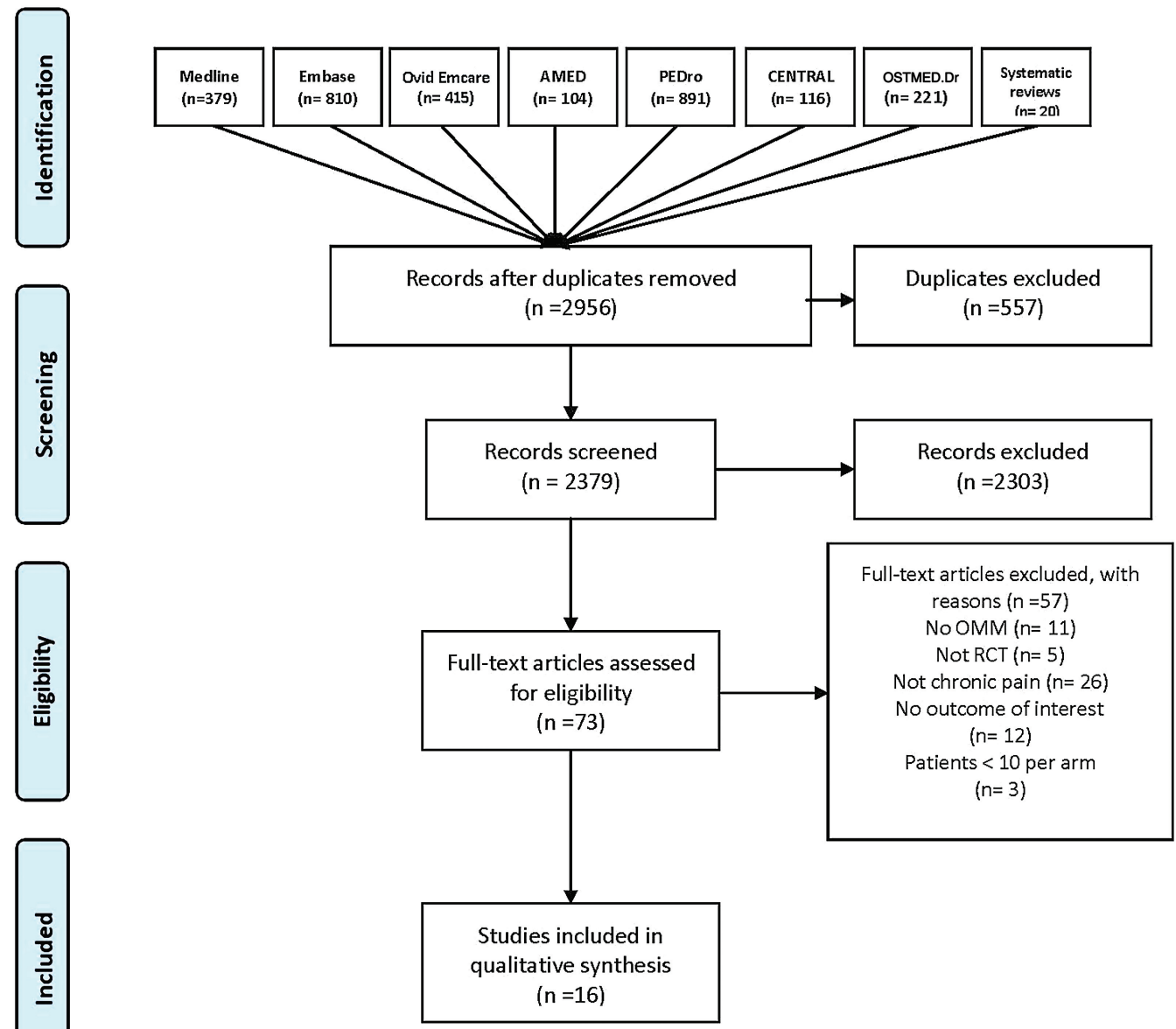

Figure 1.

Preferred Reporting Items for Systematic Reviews and Meta-Analyses (PRISMA) flow diagram. 
Table 1.

Baseline Characteristics of the Included Studies

\begin{tabular}{|c|c|c|c|c|c|c|c|c|c|}
\hline Author/ Year & $\begin{array}{l}\text { Age, } \\
\text { mean } \\
\text { (SD) }\end{array}$ & $\begin{array}{l}\text { Gender- } \\
\text { female } \\
(\%)\end{array}$ & $\begin{array}{l}\text { Pain } \\
\text { region }\end{array}$ & $\begin{array}{l}\text { Were } \\
\text { patients with } \\
\text { comorbid } \\
\text { psychologic } \\
\text { and medical } \\
\text { conditions } \\
\text { included? }\end{array}$ & $\begin{array}{l}\text { Was } \\
\text { disabilityl } \\
\text { litigation } \\
\text { considered } \\
\text { part of } \\
\text { exclusion } \\
\text { criteria? }\end{array}$ & $\begin{array}{l}\text { Were other } \\
\text { medications } \\
\text { allowed? }\end{array}$ & $\begin{array}{l}\text { Duration } \\
\text { of trial or } \\
\text { follow-up } \\
\text { period } \\
\text { (days) }\end{array}$ & $\begin{array}{l}\text { Number of } \\
\text { participants } \\
\text { in } \\
\text { intervention } \\
\text { group }\end{array}$ & $\begin{array}{l}\text { Number of } \\
\text { participants } \\
\text { in control or } \\
\text { comparison } \\
\text { groups }\end{array}$ \\
\hline Albers $2018^{37}$ & $\begin{array}{c}54.9 \\
(13.1)\end{array}$ & 3.3 & Fibromyalgia & No & NR & NR & 84 & 34 & 14 \\
\hline Altinbilek 2018 & $\begin{array}{l}54.8 \\
(8.4)\end{array}$ & 89.4 & Knee OA & Yes & NR & $\begin{array}{c}\text { No; except for } \\
\text { paracetamol }\end{array}$ & 151 & 44 & 41 \\
\hline Burton $2000^{49}$ & $\begin{array}{c}41.9 \\
(10.6)\end{array}$ & 52.5 & LBP/ LDH & Yes & Yes & NR & 365 & 15 & 15 \\
\hline Chown $2008^{52}$ & 43.6 & 58.5 & Chronic LBP & Yes & NR & $\begin{array}{c}\text { Steroids were } \\
\text { not allowed }\end{array}$ & 365 & 39 & 59 \\
\hline Cuccia $2010^{43}$ & $\begin{array}{c}39.5 \\
(13.1)\end{array}$ & 58.7 & TMD & No & NR & NR & 168 & 25 & 25 \\
\hline Knebl $2002^{42}$ & $65-85$ & 62.1 & $\begin{array}{l}\text { Chronic } \\
\text { shoulder } \\
\text { pain }\end{array}$ & Yes & $N R$ & NR & 105 & NR & NR \\
\hline $\begin{array}{l}\text { Licciardone } \\
2003^{38}\end{array}$ & $\begin{array}{l}49.9 \\
(8.0)\end{array}$ & 64.6 & $\begin{array}{l}\text { Chronic } \\
\text { nonspecific } \\
\text { LBP }\end{array}$ & Yes & Yes & Yes & 84 & 32 & 34 \\
\hline $\begin{array}{l}\text { Licciardone } \\
2013^{50}\end{array}$ & $\begin{array}{c}40.5 \\
(16.3)\end{array}$ & 62.5 & $\begin{array}{l}\text { Chronic } \\
\text { nonspecific } \\
\text { LBP }\end{array}$ & Yes & Yes & Yes & 56 & 230 & 225 \\
\hline Marske $2018^{44}$ & 51.2 & 93.2 & Fibromyalgia & No & NR & NR & 42 & $11 / 10$ & 8 \\
\hline $\begin{array}{l}\text { Marti-Salvador } \\
2018^{48}\end{array}$ & $18-60$ & NR & $\begin{array}{l}\text { Chronic } \\
\text { nonspecific } \\
\text { LBP }\end{array}$ & No & NR & No & 56 & 33 & 33 \\
\hline Papa $2012^{45}$ & $77(6.7)$ & 70.5 & $\begin{array}{c}\text { Chronic } \\
\text { nonspecific } \\
\text { body pain }\end{array}$ & Yes & $N R$ & $N R$ & 42 & 37 & 35 \\
\hline $\begin{array}{l}\text { Schwerla } \\
2008^{40}\end{array}$ & $35.4-54.2$ & 75.6 & $\begin{array}{c}\text { Chronic } \\
\text { nonspecific } \\
\text { neck pain }\end{array}$ & No & Yes & NR & 84 & 21 & 16 \\
\hline Silva $2018^{46}$ & $\begin{array}{c}25.4 \\
(8.29)\end{array}$ & NR & $\begin{array}{c}\text { Non-specific } \\
\text { neck pain }\end{array}$ & No & No & No & 7 & 14 & 14 \\
\hline Stepnik $2018^{39}$ & $23-53$ & 83.9 & $\begin{array}{l}\text { Chronic } \\
\text { Neck Pain }\end{array}$ & No & No & NR & NR & 16 & 15 \\
\hline Tamer $2017^{47}$ & $\begin{array}{l}39.9 \\
(5.1)\end{array}$ & 53.9 & $\begin{array}{l}\text { Chronic } \\
\text { nonspecific } \\
\text { LBP }\end{array}$ & No & Yes & No & 42 & 20 & 19 \\
\hline $\begin{array}{l}\text { Vismara } \\
2012^{51}\end{array}$ & $\begin{array}{l}43.7 \\
(9.8)\end{array}$ & 100 & Chronic LBP & No & Yes & NR & $N R$ & 10 & 11 \\
\hline
\end{tabular}

Abbreviations: LBP, low back pain; LDH, lumbar disc herniation; NR, not reported; OA, osteoarthritis; TMP, temporomandibular disorder. 
Table 2.

Summary of OMTh Treatments and Comparator Interventions

\begin{tabular}{|c|c|c|c|c|c|}
\hline Author/ Year & $\begin{array}{l}\text { Treatment } \\
\text { groups }\end{array}$ & $\begin{array}{l}\text { Osteopathic } \\
\text { manipulation }\end{array}$ & Comparator & $\begin{array}{l}\text { Per } \\
\text { protocol or } \\
\text { clinician } \\
\text { directed } \\
\text { therapy }\end{array}$ & $\begin{array}{l}\text { Cointervention use } \\
\text { allowed description }\end{array}$ \\
\hline Albers $2018^{37}$ & OMTh & $\begin{array}{l}\text { Direct and indirect techniques } \\
\text { (muscle energy, MFR, HVLA, } \\
\text { functional techniques, and } \\
\text { balanced ligamentous } \\
\text { tension) and cranial/sacral } \\
\text { techniques. }\end{array}$ & SC & $\begin{array}{l}\text { Clinician } \\
\text { directed }\end{array}$ & $\begin{array}{l}\text { Pharmaceutical use NR but } \\
\text { patients were excluded if } \\
\text { they underwent manual } \\
\text { therapy treatment or } \\
\text { alternative treatment } \\
\text { procedures during the study } \\
\text { period. }\end{array}$ \\
\hline $\begin{array}{l}\text { Altinbilek } \\
2018^{41}\end{array}$ & $\begin{array}{l}\text { OMTh + } \\
\text { Exercise }\end{array}$ & $\begin{array}{l}\text { Standardized mobilization and } \\
\text { compression for bilateral } \\
\text { patellofemoral and } \\
\text { tibiofemoral joints followed by } \\
\text { a lower extremity pumping } \\
\text { technique. These techniques } \\
\text { are taught to the patient to } \\
\text { apply at home as well. }\end{array}$ & $\begin{array}{l}\text { Exercise consisted of } \\
\text { quadriceps muscle } \\
\text { strengthening exercise, leg } \\
\text { lifting, and muscle stretching } \\
\text { such as iliotibial band, } \\
\text { hamstring stretching, } \\
\text { strengthening abductor and } \\
\text { adductor muscles of the hip. }\end{array}$ & Per protocol & $\begin{array}{l}\text { No - Prevented from taking } \\
\text { non-steroidal } \\
\text { anti-inflammatory drugs } 1 \\
\text { week before and during the } \\
\text { study. Paracetamol up to } 3 \mathrm{~g} / \\
\text { daily was allowed and drugs } \\
\text { for systemic conditions } \\
\text { continued. }\end{array}$ \\
\hline Burton $2000^{49}$ & OMTh & $\begin{array}{l}\text { Soft tissue stretching in } \\
\text { combination with low } \\
\text { amplitude passive articulatory } \\
\text { maneuvers and high velocity } \\
\text { thrust to the lumbar spine and } \\
\text { buttock musculature. }\end{array}$ & $\begin{array}{l}\text { Chemonucleolysis under } \\
\text { general anesthesia, a single } \\
\text { dose of chymopapain. }\end{array}$ & $\begin{array}{l}\text { Clinician } \\
\text { directed }\end{array}$ & $\begin{array}{l}\text { No - Patients with previous } \\
\text { manipulations on the same } \\
\text { area were excluded. }\end{array}$ \\
\hline Chown $2008^{52}$ & OMTh & $\begin{array}{l}\text { Soft tissue massage, } \\
\text { inhibition, muscle stretching, } \\
\text { muscle energy, high velocity } \\
\text { thrust (varying), articulation, } \\
\text { mobilization, exercise advice, } \\
\text { discussion of psychosocial } \\
\text { issues, education, nutritional/ } \\
\text { dietary advice. }\end{array}$ & $\begin{array}{l}\text { Group exercise: } \\
\text { Problem identification, } \\
\text { anatomy education, home } \\
\text { stretching exercise } \\
\text { programme, basic postural } \\
\text { setting use of transverses, } \\
\text { multifidus. } \\
\text { Manipulative } \\
\text { physiotherapy: } \\
\text { Education/advice, joint } \\
\text { mobilization, soft tissue } \\
\text { mobilization, global exercise } \\
\text { for mobility, electrotherapy, } \\
\text { postural correction. }\end{array}$ & $\begin{array}{l}\text { Clinician } \\
\text { directed }\end{array}$ & $\begin{array}{l}\text { No - Patients with } \\
\text { manipulations such as } \\
\text { physiotherapy, acupuncture } \\
\text { in the previous } 3 \text { months } \\
\text { were excluded as well as } \\
\text { users of steroids and } \\
\text { anticoagulants. }\end{array}$ \\
\hline Cuccia $2010^{43}$ & OMTh & $\begin{array}{l}\text { MFR, joint articulation, } \\
\text { membranous tension, muscle } \\
\text { energy, high-velocity, } \\
\text { low-amplitude thrust and } \\
\text { cranial-sacral therapy. }\end{array}$ & $\begin{array}{l}\text { Use of an oral appliance, } \\
\text { physical therapy, therapies } \\
\text { such as hot or cold packs } \\
\text { (or both), transcutaneous } \\
\text { electrical nerve stimulation. }\end{array}$ & $\begin{array}{l}\text { Clinician } \\
\text { directed }\end{array}$ & $\begin{array}{l}\text { Yes - Non-steroidal } \\
\text { medications, } \\
\text { anti-inflammatory, } \\
\text { analgesics and/or muscle } \\
\text { relaxants were allowed } \\
\text { when prescribed by their } \\
\text { medical practitioner }\end{array}$ \\
\hline
\end{tabular}

(continued) 
Table 2 (continued).

Summary of OMTh Treatments and Comparator Interventions

\begin{tabular}{|c|c|c|c|c|c|}
\hline Author/ Year & $\begin{array}{l}\text { Treatment } \\
\text { groups }\end{array}$ & $\begin{array}{l}\text { Osteopathic } \\
\text { manipulation }\end{array}$ & Comparator & $\begin{array}{l}\text { Per } \\
\text { protocol or } \\
\text { clinician } \\
\text { directed } \\
\text { therapy }\end{array}$ & $\begin{array}{l}\text { Cointervention use } \\
\text { allowed description }\end{array}$ \\
\hline Knebl $2002^{42}$ & OMTh & $\begin{array}{l}\text { Treatment was defined as } \\
\text { administration of the } \\
\text { seven-step Spencer } \\
\text { technique which is an articular } \\
\text { treatment involving } \\
\text { compression, traction, and } \\
\text { muscle energy in various } \\
\text { planes and axes. }\end{array}$ & $\begin{array}{l}\text { The } 7 \text { positions of the } \\
\text { Spencer technique without } \\
\text { administration of the actual } \\
\text { corrective forces (isometric } \\
\text { muscle contraction). }\end{array}$ & Per protocol & NR \\
\hline $\begin{array}{l}\text { Licciardone } \\
2003^{38}\end{array}$ & OMTh & $\begin{array}{l}\text { Combination of MFR, strain- } \\
\text { counter strain, muscle energy, } \\
\text { soft tissue, high-velocity- } \\
\text { low-amplitude thrusts, and } \\
\text { cranial-sacral. }\end{array}$ & $\begin{array}{l}\text { ROM activities, light touch, } \\
\text { and simulated OMTh } \\
\text { techniques. }\end{array}$ & $\begin{array}{l}\text { Clinician } \\
\text { directed }\end{array}$ & $\begin{array}{l}\text { Yes - Usual or other low } \\
\text { back care allowed in both } \\
\text { arms except OMTh or } \\
\text { chiropractic manipulation. }\end{array}$ \\
\hline $\begin{array}{l}\text { Licciardone } \\
2013^{50}\end{array}$ & OMTh & $\begin{array}{l}\text { The lumbosacral, iliac, and } \\
\text { pubic regions were targeted } \\
\text { using high-velocity, } \\
\text { low-amplitude thrusts; } \\
\text { moderate velocity, } \\
\text { moderate-amplitude thrusts; } \\
\text { soft tissue stretching, } \\
\text { kneading, and pressure; MFR; } \\
\text { positional treatment of } \\
\text { myofascial tender points; and } \\
\text { isometric muscle activation. }\end{array}$ & $\begin{array}{l}\text { Sham OMTh involved hand } \\
\text { contact, active and passive } \\
\text { range of motion, and } \\
\text { techniques that simulated } \\
\text { OMTh but used such } \\
\text { maneuvers as light touch, } \\
\text { improper patient positioning, } \\
\text { purposefully misdirected } \\
\text { movements, and diminished } \\
\text { physician force. }\end{array}$ & $\begin{array}{l}\text { Clinician } \\
\text { directed }\end{array}$ & $\begin{array}{l}\text { Yes - Patients could } \\
\text { self-initiate LB cotreatments } \\
\text { including prescription and } \\
\text { non-prescription drugs, } \\
\text { exercise programs, lumbar } \\
\text { supports, complementary, } \\
\text { alternative medicine and } \\
\text { physical therapies. }\end{array}$ \\
\hline Marske $2018^{44}$ & $\begin{array}{l}\text { OMTh \& } \\
\text { OMTh + } \\
\text { Gabapentin }\end{array}$ & $\begin{array}{l}\text { Treatment modalities included } \\
\text { MFR, muscle energy, counter } \\
\text { strain, facilitated positional } \\
\text { release, articular ligamentous, } \\
\text { high velocity/low amplitude, } \\
\text { and cranial sacral OMTh. } \\
\text { Indirect moving to direct as } \\
\text { tolerated by the patient. }\end{array}$ & $\begin{array}{l}\text { Gabapentin with variable } \\
\text { dose }(300 \mathrm{mg} \text { to } 900 \mathrm{mg} / \\
\text { day). }\end{array}$ & $\begin{array}{l}\text { Clinician } \\
\text { directed }\end{array}$ & $\begin{array}{l}\text { Concurrent medications } \\
\text { were continued. }\end{array}$ \\
\hline $\begin{array}{l}\text { Marti-Salvador } \\
2018^{48}\end{array}$ & $\begin{array}{l}\text { Diaphragm } \\
\text { OMTh }\end{array}$ & $\begin{array}{l}\text { Lumbar MFR, normalization of } \\
\text { the iliolumbar ligament, } \\
\text { pumping, traction to the } \\
\text { lumbar and sacral regions, } \\
\text { techniques directed to the } \\
\text { diaphragm included pumping, } \\
\text { inhibition, muscle stretching, } \\
\text { and a global abdominal } \\
\text { hemodynamic maneuver. }\end{array}$ & $\begin{array}{l}\text { Manual contact was applied } \\
\text { but with no therapeutic } \\
\text { intention. }\end{array}$ & Per protocol & $\begin{array}{l}\text { Yes - Cointerventions were } \\
\text { not analyzed - a noted } \\
\text { limitation of the study. }\end{array}$ \\
\hline
\end{tabular}


Table 2 (continued).

Summary of OMTh Treatments and Comparator Interventions

\begin{tabular}{|c|c|c|c|c|c|}
\hline Author/ Year & $\begin{array}{l}\text { Treatment } \\
\text { groups }\end{array}$ & $\begin{array}{l}\text { Osteopathic } \\
\text { manipulation }\end{array}$ & Comparator & $\begin{array}{l}\text { Per } \\
\text { protocol or } \\
\text { clinician } \\
\text { directed } \\
\text { therapy }\end{array}$ & $\begin{array}{l}\text { Cointervention use } \\
\text { allowed description }\end{array}$ \\
\hline Papa $2012^{45}$ & OMTh & $\begin{array}{l}\text { Different techniques were used } \\
\text { based on the results of the } \\
\text { exam, objective techniques } \\
\text { were performed on any body } \\
\text { part that the osteopath found } \\
\text { to be correlated with the } \\
\text { disorder and the patient's } \\
\text { functional limitation with } \\
\text { considerations to myofascial, } \\
\text { visceral, articulating and head } \\
\text { structures. }\end{array}$ & $\begin{array}{l}\text { Postural examination and } \\
\text { palpation of non-specific } \\
\text { different parts of the body in } \\
\text { different positions supine. }\end{array}$ & $\begin{array}{l}\text { Clinician } \\
\text { directed }\end{array}$ & $\begin{array}{l}\text { Yes - Patients were } \\
\text { subjected to the usual } \\
\text { therapy established as a } \\
\text { result of medical specialist } \\
\text { visits but were not reported. }\end{array}$ \\
\hline $\begin{array}{l}\text { Schwerla } \\
2008^{40}\end{array}$ & OMTh & $\begin{array}{l}\text { Osteopathic techniques } \\
\text { included direct techniques } \\
\text { (high velocity, muscle energy, } \\
\text { MFR), indirect techniques } \\
\text { (functional techniques, } \\
\text { balanced ligamentous } \\
\text { tension), visceral and/or } \\
\text { cranial techniques. }\end{array}$ & Inert therapeutic ultrasound. & $\begin{array}{l}\text { Clinician } \\
\text { directed }\end{array}$ & $\begin{array}{l}\text { Yes - Excluded patients with } \\
\text { concomitant physical } \\
\text { therapy, corticosteroid use, } \\
\text { anticoagulants. Patients } \\
\text { kept a diary of analgesic } \\
\text { and muscle relaxant use. }\end{array}$ \\
\hline Silva $2018^{46}$ & OMTh & $\begin{array}{l}\text { Osteopathic manipulation } \\
\text { technique to the stomach } \\
\text { followed by the liver. }\end{array}$ & $\begin{array}{l}\text { Placebo manipulation } \\
\text { technique }\end{array}$ & Per protocol & $\begin{array}{l}\text { No - Patients using } \\
\text { analgesics, muscle relaxants } \\
\text { and anti-inflammatory drugs } \\
\text { in the } 5 \text { days prior to the } \\
\text { intervention were excluded. }\end{array}$ \\
\hline Stepnik $2018^{39}$ & OMTh & $\begin{array}{l}\text { Osteopathic techniques } \\
\text { employed } 5 \text { specific } \\
\text { techniques to the anterior } \\
\text { neck region. These included } \\
\text { superficial fascia stretch, } \\
\text { pretracheal fascia stretch, } \\
\text { carotid sheath stretches, deep } \\
\text { cervical fascia stretches, and } \\
\text { suspensory ligament of } \\
\text { pleural cupula stretch }\end{array}$ & $\begin{array}{l}\text { Laser therapy using Polaris } \\
2 \text { laser (turned off) }\end{array}$ & Per protocol & NR \\
\hline Tamer $2017^{47}$ & vOMTh & $\begin{array}{l}\text { Soft tissue mobilization, } \\
\text { muscle-energy techniques, } \\
\text { manipulation and mobilization } \\
\text { for lumbar and thorax regions, } \\
\text { lymphatic and liver pumping } \\
\text { techniques, pelvic floor, } \\
\text { diaphragm relaxation } \\
\text { techniques, arterial, venous } \\
\text { and neural techniques, fascial } \\
\text { mobilization for visceral } \\
\text { organs. }\end{array}$ & $\begin{array}{l}\text { Soft-tissue mobilizations, } \\
\text { muscle-energy techniques, } \\
\text { manipulation and } \\
\text { mobilization for lumbar and } \\
\text { thorax regions. }\end{array}$ & $\begin{array}{l}\text { Clinician } \\
\text { directed }\end{array}$ & $\begin{array}{l}\text { Yes - Physiotherapy used in } \\
\text { conjunction with both } \\
\text { treatment arms aimed at } \\
\text { spinal stabilization } \\
\text { strengthening and } \\
\text { stretching. }\end{array}$ \\
\hline
\end{tabular}




\section{Table 2 (continued).}

\section{Summary of OMTh Treatments and Comparator Interventions}

\begin{tabular}{|c|c|c|c|c|c|}
\hline Author/ Year & $\begin{array}{l}\text { Treatment } \\
\text { groups }\end{array}$ & $\begin{array}{l}\text { Osteopathic } \\
\text { manipulation }\end{array}$ & Comparator & $\begin{array}{l}\text { Per } \\
\text { protocol or } \\
\text { clinician } \\
\text { directed } \\
\text { therapy }\end{array}$ & $\begin{array}{l}\text { Cointervention use } \\
\text { allowed description }\end{array}$ \\
\hline Vismara $2012^{51}$ & $\mathrm{OMTh}+\mathrm{SE}$ & $\begin{array}{l}\text { High-velocity, low-amplitude } \\
\text { thrust in thoracic spine, cranial } \\
\text { techniques, and MFR at the } \\
\text { practitioner's discretion. }\end{array}$ & $\begin{array}{l}\text { Active exercises, and } \\
\text { education: reinforcing and } \\
\text { stretching of the back } \\
\text { muscles; self-mobilizing the } \\
\text { spine and pelvis; posture } \\
\text { and breathing techniques; } \\
\text { providing patients with } \\
\text { correct ergonomic } \\
\text { knowledge for the safe use } \\
\text { of the spine and information } \\
\text { on the changes in spinal } \\
\text { physiology, pain, and } \\
\text { posture as related to obesity } \\
\text { and other risk factors. }\end{array}$ & $\begin{array}{l}\text { Clinician } \\
\text { directed }\end{array}$ & NR \\
\hline
\end{tabular}

Abbreviations: CCT, conventional conservative therapy; HVLA, high velocity low amplitude; MFR, myofascial release; MT, manual therapy; NR, not reported; OMTh, osteopathic manual therapy; ROM, range of motion; SC, standard care; SE, specific exercise; vOMTh, visceral osteopathic manual therapy.

joint (TMJ) pain, ${ }^{43}$ fibromyalgia, ${ }^{37,44}$ or nonspecific musculoskeletal pain. $^{45}$ Except for 7 studies, ${ }^{39,40,43,44,46-48}$ all others excluded patients with other medical or psychologic conditions. Six studies $^{38,40,47,49-51}$ excluded patients with disability claims or with ongoing litigation. Six studies specifically stated excluding patients with cancer. ${ }^{37,38,40,41,48,50}$ Only 2 authors ${ }^{48,50}$ accounted for missing data in their RTCs.

Description of OMTh and treatments are given in Table 2. Overall, methods of osteopathic treatments used were per protocol or were clinician directed. Most studies were specific in stating that treatment methods were up to the discretion of the practitioner, whereas a few studies ${ }^{42,47,48}$ attempted to employ a specific treatment protocol. Comparators vary from SC or sham, ${ }^{37-40,43,45,50}$ pharmacologic, ${ }^{44}$ exercise or physiotherapy, ${ }^{41,51,52}$, other OMTh, ${ }^{46-48}$ and chemonucleolysis. ${ }^{49}$

\section{Risk of Bias}

A summary of the ROB is given in Table 3. None of the included studies met all criteria for ROB. Except for 2 studies, ${ }^{39,43}$ all other studies were low risk for allocation concealment and random sequence generation. Except for 7 studies, ${ }^{37,39,40,43,47,49,51}$ outcomes were assessed by an independent evaluator, whereas in 2 studies patients were blinded to manipulation. ${ }^{42,46}$

\section{Pooled Analysis}

Pain severity: Among the 16 studies, poolable data were available from 13 studies. ${ }^{37-41,43,45-48,50-52}$ The collective sample size from all poolable studies for pain outcomes was 996. In total, we had 3 pooled analyses based on OMTh and comparators for pain severity (Figure 2). The GRADE is reported in Table 4.

OMTh vs. SC: Six studies ${ }^{37,38,40,43,45,50}$ with 710 patients were included in this analysis. Moderate quality evidence showed that as compared to SC, OMTh was significantly associated with pain reduction [SMD $(95 \% \mathrm{CI})=-.37(-.58,-.17)]$.

Visceral OMTh vs. general OMTh: Three studies ${ }^{46-48}$ with 133 patients were included in this analysis. Moderate quality evidence showed that, as 
Table 3.

Risk of Bias in the Included Studies

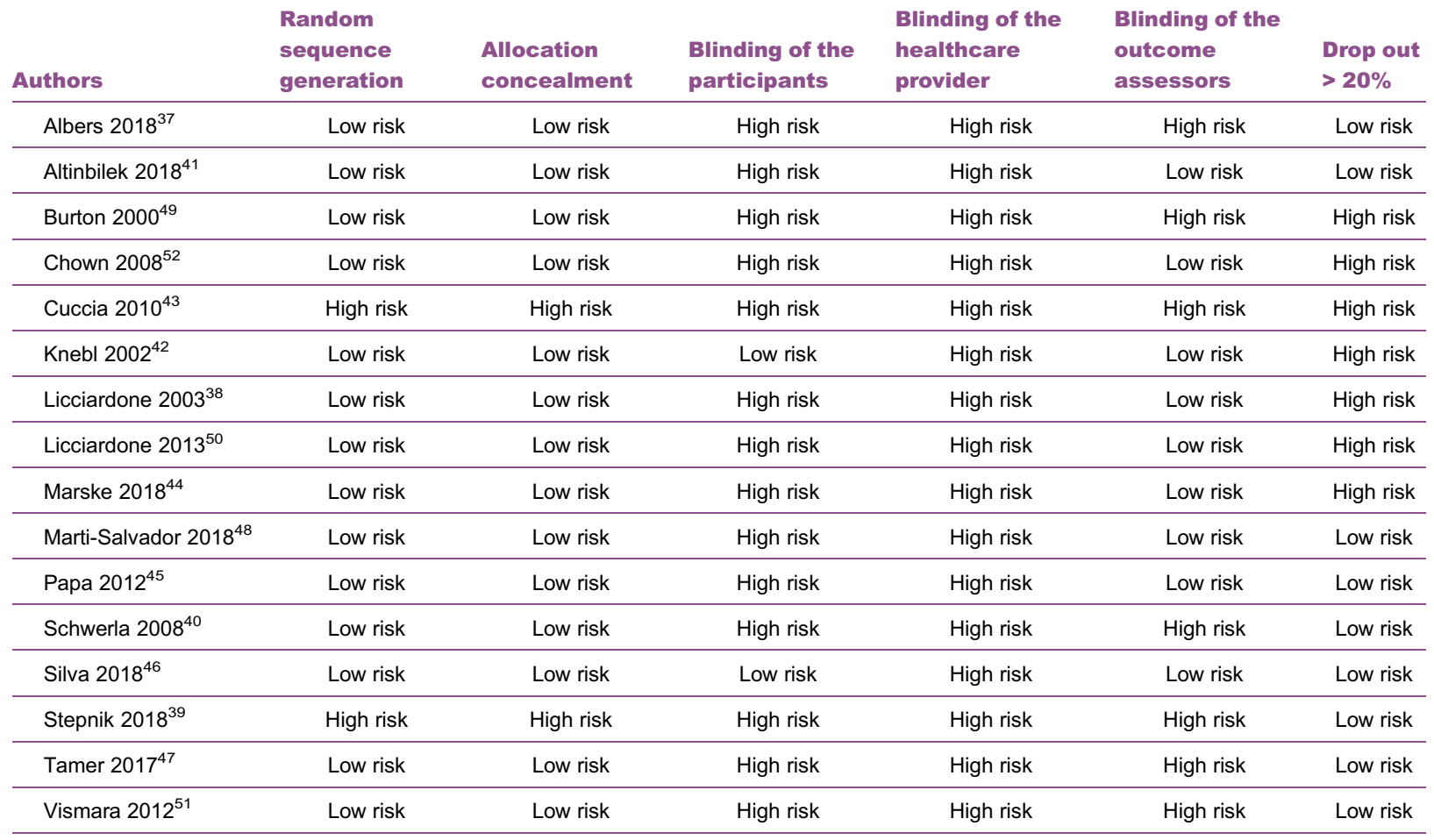

compared to general OMTh [gOMTh], visceral OMTh [ $v \mathrm{OMTh}]$ was significantly associated with pain reduction [SMD $(95 \% \mathrm{CI})=-.74(-1.09,-.39)]$.

OMTh plus exercise vs. exercise only: Two studies ${ }^{41,51}$ with 106 patients were included in this analysis. Moderate quality evidence showed that OMTh in combination with exercise was significantly associated with pain reduction $[\operatorname{SMD}(95 \% \mathrm{CI})=-1.25(-1.67,-.83)]$.

\section{Disability}

Of the eligible 16 studies, poolable data concerning disability was available from 8 studies. ${ }^{39,41,47-52}$ The collective sample size from all poolable studies for disability outcomes was 742 . There were 3 pooled analyses based on OMTh and the various comparators in total (Figure 3A-C).

OMTh vs. SC: Two studies ${ }^{40,50}$ with 486 patients were included in this analysis. Moderate quality evi- dence showed that, as compared with SC, OMTh was significantly associated with reduction in disability and/or function [SMD $(95 \% \mathrm{CI})=-1.04(-1.23,-.85)]$.

vOMTh vs. gOMTh: Two studies ${ }^{47,48}$ with 105 patients were included in this analysis. Moderate quality evidence showed that $v \mathrm{OMTh}$ as compared to gOMTh was significantly associated with improvement in disability $(\mathrm{SMD}(95 \% \mathrm{CI})=-.52(-.91,-.13)]$.

OMTh plus exercise vs. exercise only: Two studies ${ }^{41,51}$ with 106 patients were included in this analysis. Moderate quality evidence showed that OMTh combined with exercise as compared to exercise alone was significantly associated with improvement in disability [SMD $(95 \% \mathrm{CI})=-1.15(-1.57,-.74)]$.

Quality of life: Of the eligible 16 studies, poolable data were available from 2 studies. ${ }^{37,45}$ The collective sample size from all poolable studies for QOL outcomes was 120 . Due to the small number of studies, 


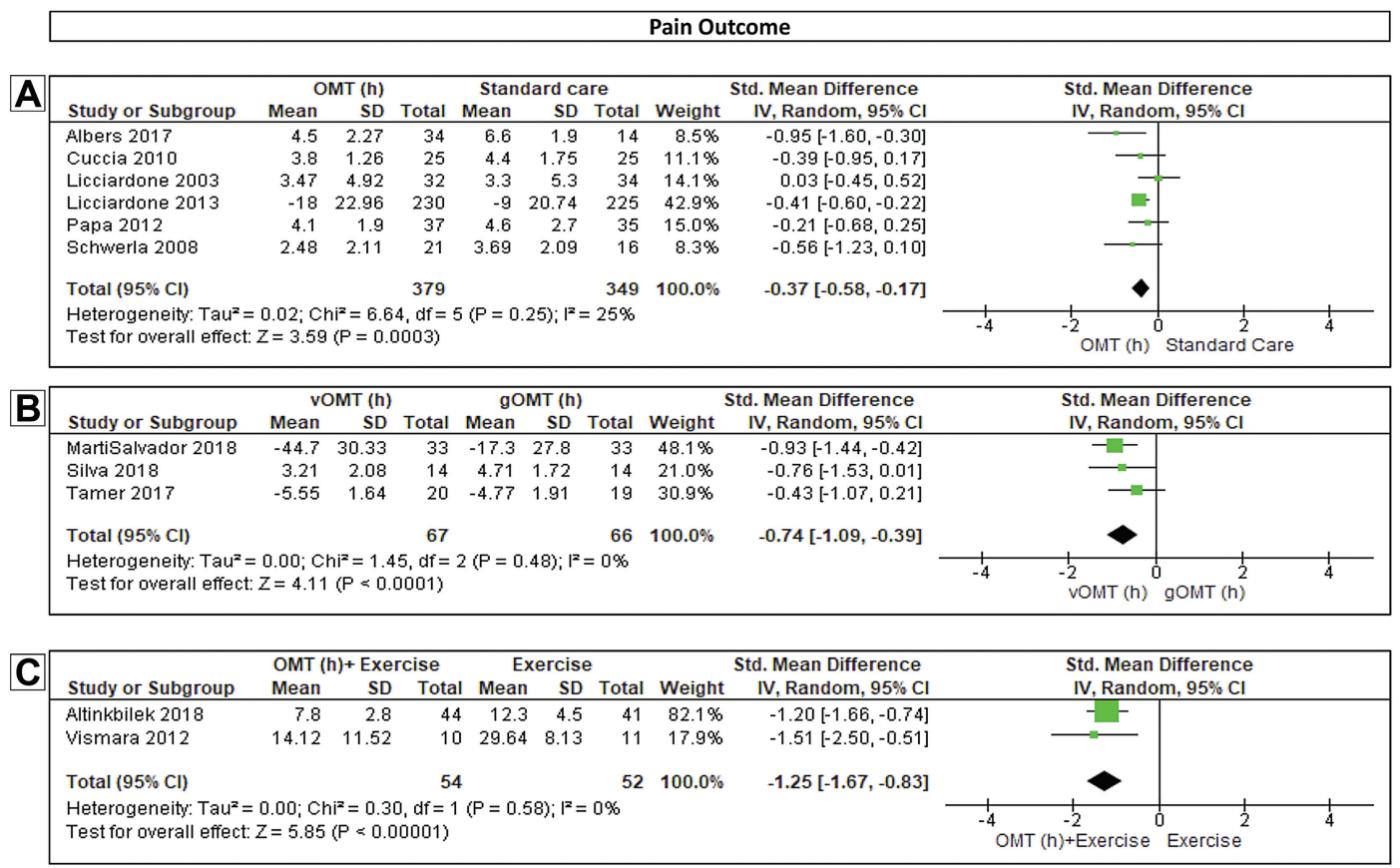

Figure 2.

Pain outcome. (A) OMT vs. standard care, (B) vOMTh vs. gOMTh, (C) OMT + excercise vs. exercise.

Abbreviations: OMT, osteopathic manipulative treatment; gOMTh, general osteopathic manipulative therapy; OMTh, osteopathic manipulative therapy; vOMTh, visceral osteopathic manipulative therapy.

we had single pooled analysis (Figure 3D). Moderate quality evidence showed that OMTh was significantly associated with improved QOL as compared to SC [SMD $(95 \% \mathrm{CI})=.67(.29,1.05)]$.

For any of the pooling with FEM, the effect size did not change when reanalyzed with REM. The summary of the non-poolable studies and RTW are given in Table 5. Three studies ${ }^{38,49,50}$ showed that the effects of OMTh on pain, disability, and RTW were short term, with the effect declining by final follow up.

Return to work: Two studies ${ }^{38,50}$ explored the effectiveness of OMTh on RTW. Licciardone et $\mathrm{al}^{50}$ reported improvements in the number of days of work missed within 4 weeks. Patients in the OMTh group had significant RTW at 4 weeks, but not at 12-week follow up.

Subgroup and sensitivity analysis: We performed a sensitivity analysis that was based on LBP but ignored differences in OMTh intervention and comparators and found high heterogeneity $\left(\mathrm{I}^{2}=59 \% ; \quad P=.0006\right.$;
Figure 4A), which supports the rationale to pool according to OMTh types and comparators. Similarly, the subgroup analysis between sham and SC comparators did not show any significant differences between the two subgroups. The test of interaction $\left(\mathrm{I}^{2}=61.4 \%\right.$; $P=.11$ ) between both groups was not significant, thus justifying our reason to pool sham and SC comparators together (Figure 4B).

\section{Discussion}

Overall, our results indicate OMTh can be employed as an effective treatment approach for CNCP patients. Moderate quality evidence showed that $v \mathrm{OMTh}$ was significantly associated with reduction in pain severity and disability. OMTh in combination with exercise (vs. exercise only) was significantly associated with reduction in pain severity and disability. Although OMTh was not significantly associated with RTW 


\section{Table 4.}

GRADE Table (Quality of Evidence)

\begin{tabular}{|c|c|c|c|c|c|c|c|}
\hline Intervention & $\begin{array}{l}\text { Number of } \\
\text { studies and } \\
(n=)\end{array}$ & $\begin{array}{l}\text { Risk of } \\
\text { bias }\end{array}$ & Inconsistency & Imprecision & Indirectness & $\begin{array}{c}\text { Publication } \\
\text { bias }\end{array}$ & $\begin{array}{l}\text { Quality of } \\
\text { evidence }\end{array}$ \\
\hline \multicolumn{8}{|l|}{ Pain severity } \\
\hline $\begin{array}{l}\text { OMTh + Exercise vs. } \\
\text { Exercise (Moderate) }\end{array}$ & $2(n=106)$ & High & Low risk & Precise & Not detected & Not detected & $0+++$ \\
\hline $\begin{array}{l}\text { OMTh vs. SC } \\
\text { (Moderate) }\end{array}$ & $6(n=710)$ & High & Low risk & Precise & Not detected & Not detected & $0+++$ \\
\hline $\begin{array}{l}\text { vOMTh vs. gOMTh } \\
\text { (Moderate) }\end{array}$ & $3(n=133)$ & High & Low risk & Precise & Not detected & Not detected & $0+++$ \\
\hline \multicolumn{8}{|l|}{ Disability } \\
\hline $\begin{array}{l}\text { vOMTh vs. gOMTh } \\
\text { (Moderate) }\end{array}$ & $2(n=79)$ & High & Low risk & Precise & Not detected & Not detected & $0+++$ \\
\hline $\begin{array}{l}\text { OMTh vs. SC } \\
\text { (Moderate) }\end{array}$ & $2(n=486)$ & High & Low risk & Precise & Not detected & Not detected & $0+++$ \\
\hline $\begin{array}{l}\text { OMTh + Exercise vs. } \\
\text { Exercise (Moderate) }\end{array}$ & $2(n=106)$ & High & Low risk & Precise & Not detected & Not detected & $0+++$ \\
\hline \multicolumn{8}{|l|}{ Quality of life } \\
\hline $\begin{array}{l}\text { OMTh vs. SC } \\
\text { (Moderate) }\end{array}$ & $2(n=120)$ & High & Low & Precise & Not detected & Not detected & $0+++$ \\
\hline
\end{tabular}

Risk of bias among all the included studies was high, which lowers the quality of evidence.

Abbreviations: gOMTh, general OMTh; GRADE, Grading of Recommendations Assessment, Development, and Evaluation; OMTh, osteopathic manual therapy; SC, standard care; VOMTh, visceral OMTh.

compared to SC, it showed significant effects in reducing pain, disability, and improving QOL. When compared with other interventions such as chemonucleolysis, physiotherapy, and pharmacologic agents, OMTh did not show significant improvements in pain severity, disability, or QOL; however, the evidence regarding OMTh in comparison with chemonucleolysis, physiotherapy, and gabapentin is based on single studies.

\section{Strengths and Limitations}

The key strengths of our review were that, first, we focused on broader patient important outcomes such as reduction in pain severity, functional limitations, improvement in QOL, and RTW. Second, our search strategy was broad and up to date, and methodologic- ally our review was very rigorous, because we reported our results clearly and transparently, allowing for more precise interpretation. Third, this is, to the best of our knowledge, the first systematic review and meta-analysis that pooled studies based on the similarity between the interventions and comparators, which acted to reduce the heterogeneity in our pooled analyses. We performed a sensitivity analysis based on LBP, ignoring the differences in OMTh and comparators as in previous reviews, and found that heterogeneity was $59 \%(p=.02)$, thus supporting our rationale to pool studies based on homogeneity of comparator.

Our review also had several limitations. First, we inherited limitations from the primary studies, such as high ROB, for which we downrated quality of evidence for major bias components such as random sequence 


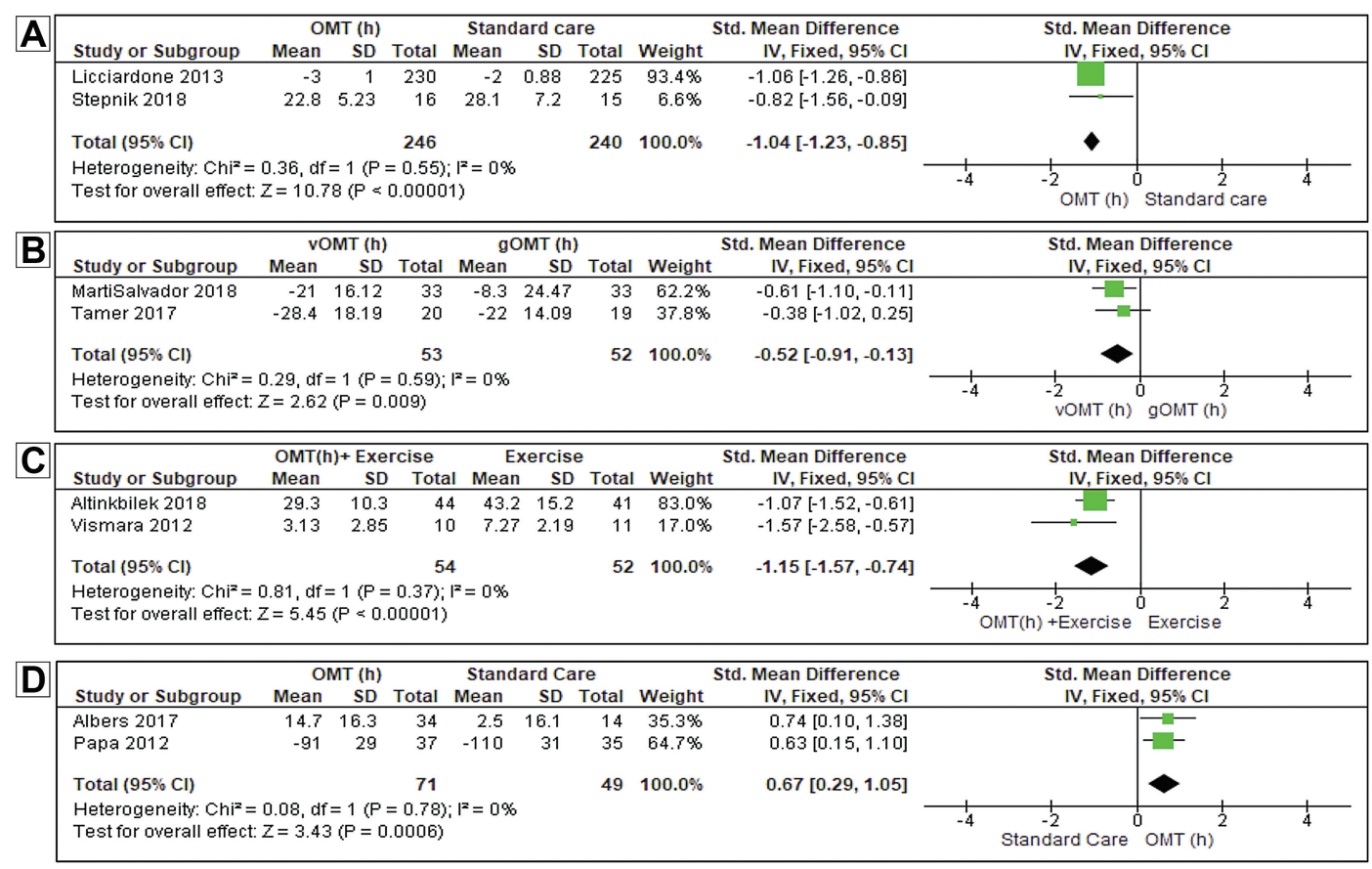

Figure 3.

Disability outcomes (A) OMTh vs. standard care, (B) vOMTh vs. gOMTh, (C) OMTh + exercise vs. exercise, and (D) quality of life outcome measure, standard care vs OMTh.

Abbreviations: OMT, osteopathic manipulative treatment; gOMTh, general osteopathic manipulative therapy; OMTh, osteopathic manipulative therapy; vOMTh, visceral osteopathic manipulative therapy.

generation and lack of blinding. Although none of the included studies in our review met all criteria of ROB, this is a common limitation to all procedure-based clinical trials, because it is nearly impossible to blind both patients and practitioner(s). Second, the eligible studies were not powered enough and dropout rate in the eligible studies was very high; except for 2 studies, ${ }^{48,50}$ no others accounted for missing data. Small sample sizes and high dropout rates increase the risk of error in interpreting the results because of overor underestimating the effect. ${ }^{53,54}$ This was obvious in the study ${ }^{50}$ that used a large sample size and intention to treat; the results were more precise than any other study with a small sample size in pooled analyses. Third, we did not have enough studies to do subgroup analyses based on our a priori evidence as reported in the protocol, including ROB, duration of chronic pain, and frequency of OMTh; comorbid psychologic and/or medical conditions; and the use of cointerventions. Fourth, because of the nature of current evidence, we were unable to explore the effectiveness of OMTh in comparison to medical interventions in a pooled analysis ${ }^{44}$ and, because of incomplete reporting of data, many studies were unpoolable, ${ }^{42,49,52}$ particularly for RTW. ${ }^{38,50}$

Most of our findings align with previous systematic reviews ${ }^{28-30}$; however, our pooled results showed lower heterogeneity. High heterogeneity in a pooled analysis can confound the interpretation of the results ${ }^{55-57}$ and often indicates that studies are either clinically or methodologically different and should be reported descriptively. ${ }^{35}$ As with previous reviews, ${ }^{28-30}$ the quality of evidence (GRADE assessment) in our review was moderate. Previous reviews downrated the GRADE assessment for high heterogeneity but not for high ROB. With respect to ROB, random sequence generation and 
Table 5.

Outcomes of Unpoolable Studies

\begin{tabular}{|c|c|c|c|c|}
\hline \multirow[b]{2}{*}{ Author } & \multicolumn{2}{|c|}{$\begin{array}{l}\text { Number of } \\
\text { participants analyzed }\end{array}$} & \multirow[b]{2}{*}{ Outcome measuring scale } & \multirow[b]{2}{*}{ Conclusion ES=SMD $(95 \% \mathrm{CI})$} \\
\hline & OMTh & Comparator & & \\
\hline \multicolumn{5}{|c|}{ Pain } \\
\hline Burton $2000^{49}$ & 15 & 15 & VAS & $\begin{array}{l}\text { At the beginning of the treatments, OMTh showed } \\
\text { significant improvement in pain severity but at } 12 \text { months } \\
\text { follow up the effect was not significant. } E S=-.07[-.79, .64]\end{array}$ \\
\hline Knebl $2002^{42}$ & NR & NR & Pain rating scale $(0-10)$ & $\begin{array}{l}\text { A total of } 29 \text { subjects were randomly assigned to either a } \\
\text { treatment }(\mathrm{OMTh}) \text { group or a control group for } 14 \text { weeks } \\
\text { had significantly decreased perceived pain }(P<.01) \text {. }\end{array}$ \\
\hline Marske $2018^{44}$ & 10 & 8 & WBF & $\begin{array}{l}\text { OMTh + Gabapentin vs. Gabapentin: Within group } \\
\text { difference showed that Patients receiving combination of } \\
\text { OMTh and Gabapentin had significant improvement in the } \\
\text { pain reduction }[-2.9(-5.6,-.3) \text { vs. }-.6(-3.2,2)] \text { respectively. } \\
\text { Between group difference showed no significant } \\
\text { improvement between combination of OMTh } \\
\text { and gabapentin vs. gabapentin alone. ES=-. } 65[-1.61, .31]\end{array}$ \\
\hline
\end{tabular}

118

OMTh vs. Gabapentin: within group difference showed that patients receiving OMTh had significant improvement in the pain reduction as compared to the gabapentin alone [-2.4 $(-4.0,-.80$ vs. $-.6(-3.2,2)]$ respectively. Between group difference showed no significant difference between OMTh vs. gabapentin. $E S=-.64[-1.57,0.30]$

\begin{tabular}{|c|c|c|c|c|}
\hline \multicolumn{5}{|c|}{ Disability outcomes } \\
\hline Burton $2000^{49}$ & 15 & 15 & $\mathrm{RDQ}$ & $\begin{array}{l}\text { At the beginning of the treatments, OMTh showed } \\
\text { significant improvement in disability but at } 12 \text { months follow } \\
\text { up the effect was not significant. ES }=-.22[-.93,0.5]\end{array}$ \\
\hline Chown $2008^{52}$ & 39 & $\begin{array}{l}\text { Group } \\
\text { Exercise }=35 \\
\text { Physiotherapy }=24\end{array}$ & ODI & $\begin{array}{l}\text { OMTh vs. Exercise= Within group difference showed } \\
\text { reduction in disability for OMTh, physiotherapy and group } \\
\text { exercises }[-5.0(-1.6 \text { to }-8.4)],[-4.1(-1.4 \text { to }-6.9)] \text { and } \\
\text { [-4.5 }(-.9 \text { to }-8)] \text { respectively. Between group difference } \\
\text { for OMTh vs. Physiotherapy and OMTh vs. group exercises } \\
\text { were non-significant }[-.09(-.55, .37)] ;[-.05[(-.56, .46)] \text {, } \\
\text { respectively. }\end{array}$ \\
\hline \multirow{2}{*}{$\begin{array}{l}\text { Licciardone } \\
2003^{38}\end{array}$} & \multirow[t]{2}{*}{32} & Sham $=19$ & \multirow[t]{2}{*}{ RMDQ } & \multirow{2}{*}{$\begin{array}{l}\text { There was improvement initially, but it declined with time. } \\
\text { However, there were no significant changes over time } \\
\text { among the treatment groups in the RMDQ. }\end{array}$} \\
\hline & & $\begin{array}{l}\text { No } \\
\text { intervention=15 }\end{array}$ & & \\
\hline \multicolumn{5}{|c|}{ Quality of Life outcome } \\
\hline \multirow[t]{3}{*}{ Chown $2008^{52}$} & \multirow[t]{3}{*}{28} & $\begin{array}{l}\text { Group } \\
\text { Exercise=35 }\end{array}$ & \multirow[t]{3}{*}{ Euro-QOL } & \multirow{3}{*}{$\begin{array}{l}\text { Patients in the physiotherapy group and OMTh group had a } \\
\text { significant improvement in the QOL at } 6 \text { months [ } 0.10(.01 \\
\text { to .18)] and [.11 (.02 to .19)] respectively but not in group } \\
\text { exercise [.08 (-.02 to .18)]. } \\
\text { Between group difference showed no significant } \\
\text { improvement in OMTh vs. physiotherapy and OMTh vs. } \\
\text { group exercise }[.04(-.41, .50)] \text { and }[.13(-.40, .66)] \\
\text { respectively. }\end{array}$} \\
\hline & & Physiotherapy= 4 & & \\
\hline & & & & \\
\hline
\end{tabular}


Table 5 (continued).

Outcomes of Unpoolable Studies

\begin{tabular}{|c|c|c|c|c|}
\hline \multirow[b]{2}{*}{ Author } & \multicolumn{2}{|c|}{$\begin{array}{l}\text { Number of } \\
\text { participants analyzed }\end{array}$} & \multirow[b]{2}{*}{ Outcome measuring scale } & \multirow[b]{2}{*}{ Conclusion ES=SMD (95\% CI) } \\
\hline & OMTh & Comparator & & \\
\hline $\begin{array}{l}\text { Licciardone } \\
2003^{38}\end{array}$ & 32 & 34 & $\begin{array}{l}\text { SF-36- Physical component } \\
\text { summary }\end{array}$ & $\begin{array}{l}\text { OMTh was not significantly associated with improvement in } \\
\text { physical component summary score. } E S=.08[-.40, .57]\end{array}$ \\
\hline $\begin{array}{l}\text { Licciardone } \\
2013^{50}\end{array}$ & 230 & 225 & SF-36 - General health & $\begin{array}{l}\text { OMTh was not significantly associated with improvement in } \\
\text { overall general health. } E S=0[-.18, .18] .\end{array}$ \\
\hline $\begin{array}{l}\text { Schwerla } \\
2008^{40}\end{array}$ & 22 & 18 & QOL, SF-36 - Bodily pain & $\begin{array}{l}\text { The values of the osteopathic group showed better results } \\
\text { for all aspects and a significant reduction for 'bodily pain' } \\
(P=.019) \text {. }\end{array}$ \\
\hline \multicolumn{5}{|c|}{ Return to Work } \\
\hline \multirow{2}{*}{$\begin{array}{l}\text { Licciardone } \\
2003^{38}\end{array}$} & \multirow[t]{2}{*}{32} & Sham $=19$ & \multirow{2}{*}{$\begin{array}{l}\text { Number of lost workdays in the } \\
\text { past } 4 \text { weeks }\end{array}$} & \multirow{2}{*}{$\begin{array}{l}\text { There were no substantial changes among the treatment for } \\
\text { lost work or school days over time. }\end{array}$} \\
\hline & & $\begin{array}{l}\text { No } \\
\text { intervention=15 }\end{array}$ & & \\
\hline $\begin{array}{l}\text { Licciardone } \\
2013^{50}\end{array}$ & 180 & 180 & $\begin{array}{l}\text { Number of lost workdays in the } \\
\text { past } 4 \text { weeks }\end{array}$ & $\begin{array}{l}\text { The OMTh participants were less likely than the sham } \\
\text { OMTh participants to report work disability due to LBP at } \\
\text { the week } 4 \text { and } 8 \text { mark, respectively. Neither of the groups } \\
\text { showed significant improvements at week } 12 \text {. }\end{array}$ \\
\hline
\end{tabular}

Abbreviations: ES, standard mean deviation (95\% confidence interval); LBP, low back pain; NR, not reported; ODI, Oswestry Disability Index; OMTh, osteopathic manual therapy; QOL, quality of life; RDQ, Reflux Disease Questionnaire; RMDQ, Roland Morris Disability Questionnaire; SF-36, Short Form Health Survey; SMD, standardized mean difference; VAS, visual analog scale; WBF, Wong-Baker FACES Pain Rating Scale.

blinding are considered major influencers ${ }^{56,57}$ and will lower the confidence. We downrated the quality of evidence for high ROB, but heterogeneity in our pooled analyses was low, which makes the interpretation more transparent. A few studies in our review identified the effect of OMTh as short term ${ }^{30,38,43,49,50}$; similar findings were also reported in previous studies ${ }^{26}$ and are a common occurrence with other manipulation techniques. ${ }^{58,59}$ As compared to previous reviews, our search strategy was broader, more up to date, and included studies with $\mathrm{CNCP}^{28-30}$ and $\mathrm{RCTs}^{27,60}$ only. We were also cautious about not including duplicate or substudies of the main trials, which was a limitation of a previous review. $^{26}$

\section{Clinical Implications}

There was moderate quality evidence that OMTh is effective in reducing pain severity and disability and improving QOL. An interesting finding in our review was that pain symptoms improved with OMTh, although OMTh provided significant RTW at 4 weeks but not at 12-week follow up. It is important to consider that reduction in pain may not necessarily be the only contributor, because RTW also depends on the psychologic and physical demands of the individual's workplace. ${ }^{61}$ As we focused on patient-important outcomes, there is a potential that improvements in pain, disability, and QOL with OMTh will improve patient's psychosocial well-being and self-esteem, which may enhance the likelihood of RTW. This might also be considered as evidence that, because of chronicity and deconditioning associated with $\mathrm{CNCP}$, more frequent and longer courses of OMTh will be helpful with the multiple aspects of involvement, because the pathophysiology becomes more complex and maintains achieved levels of musculoskeletal function. ${ }^{62-64}$ 


\begin{tabular}{|c|c|c|c|c|c|c|c|c|c|c|c|c|}
\hline \multirow{2}{*}{$\mathbf{A}$} & \multirow[b]{2}{*}{ Study or Subgroup } & \multicolumn{3}{|c|}{ OMT (h) } & \multicolumn{3}{|c|}{ Control } & \multicolumn{2}{|r|}{ Std. Mean Difference } & \multirow{2}{*}{\multicolumn{3}{|c|}{$\begin{array}{l}\text { Std. Mean Difference } \\
\text { IV, Random, } 95 \% \mathrm{Cl}\end{array}$}} \\
\hline & & Mean & SD & Total & Mean & SD & Total & Weight & IV, Random, $95 \% \mathrm{Cl}$ & & & \\
\hline & Burton 2000 & 2.13 & 1.92 & 15 & 2.27 & 1.75 & 15 & $10.5 \%$ & $-0.07[-0.79,0.64]$ & & $\Longrightarrow$ & \\
\hline & Chown 2008 & -5 & 10.5 & 28 & -4.1 & 8 & 37 & $15.5 \%$ & $-0.10[-0.59,0.39]$ & & - & \\
\hline & Licciardone 2003 & 3.47 & 4.92 & 32 & 3.3 & 5.3 & 34 & $15.8 \%$ & $0.03[-0.45,0.52]$ & & - & \\
\hline & Licciardone 2013 & -18 & 22.96 & 230 & -9 & 20.74 & 225 & $24.6 \%$ & $-0.41[-0.60,-0.22]$ & & - & \\
\hline & MartiSalvador 2018 & -44.7 & 30.33 & 33 & -17.3 & 27.8 & 33 & $15.0 \%$ & $-0.93[-1.44,-0.42]$ & & - & \\
\hline & Tamer 2017 & -5.6 & 1.64 & 20 & -4.77 & 1.91 & 19 & $12.0 \%$ & $-0.46[-1.09,0.18]$ & & & \\
\hline & Vismara 2012 & 3.13 & 2.85 & 10 & 7.27 & 2.19 & 11 & $6.6 \%$ & $-1.57[-2.58,-0.57]$ & & & \\
\hline & Total $(95 \% \mathrm{Cl})$ & & & 368 & & & 374 & $100.0 \%$ & $-0.42[-0.71,-0.12]$ & & $>$ & \\
\hline & $\begin{array}{l}\text { Heterogeneity: } \mathrm{Tau}^{2} \\
\text { Test for overall effect }\end{array}$ & $\begin{array}{l}0.08 ; C l \\
Z=2.76\end{array}$ & $\begin{array}{l}\mathrm{i}^{2}=14 . \\
(P=0 .\end{array}$ & $\begin{array}{l}79, \mathrm{df}= \\
006)\end{array}$ & $=6(P$ & $02) ; l^{2}$ & $=59 \%$ & & & -4 & -2 OMT (h) ${ }^{0}{ }^{2}$ & 4 \\
\hline
\end{tabular}

B

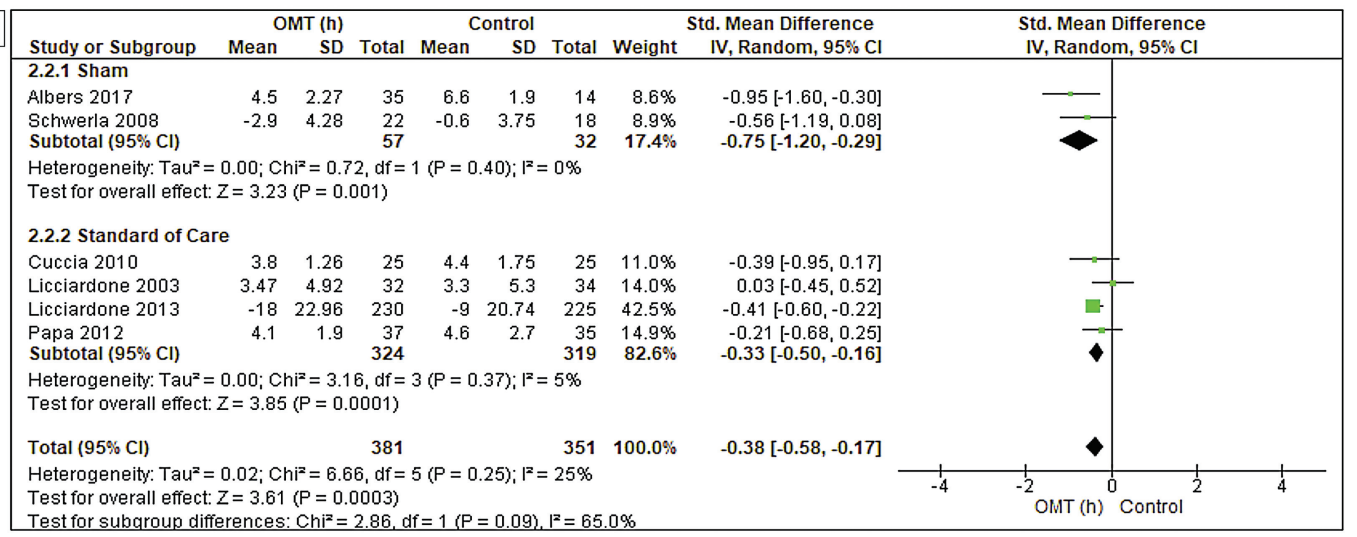

Figure 4.

Sensitivity and subgroup analysis. (A) Based on low back pain while ignoring the OMTh type and comparator type.

(B) Based to compare the sham OMTh vs. standard care (pain severity). Abbreviations: OMTh, osteopathic manipulative therapy.

Another important finding in our review is that when $v \mathrm{OMTh}$ techniques were included in treatment, there was improved effectiveness as compared to gOMTh techniques in pain reduction and disability. Possible explanations for this might be a greater consideration for the anatomic and fascial connections relative to viscero-somatic reflexes potentially involved in LBP, which constitutes key osteopathic philosophy. ${ }^{64-66}$

\section{Conclusion}

This is the most comprehensive review to date, to our knowledge, done with methodologic rigor that considers the effectiveness of OMTh in CNCP. Our findings provide evidence that OMTh alone or in combination with exercise is effective in pain, disability and increasing QOL. vOMTh techniques are proven more effective than gOMTh, which does not consider visceral involvement. Due to the more complex pathophysiology involved, more frequent regular OMTh might provide better results. ${ }^{62-64}$ Our results should, however, be interpreted cautiously because of small sample sizes, high ROB, and high dropout rates. In the future, there is a need for high quality RCTs with larger sample sizes to better demonstrate the effectiveness of OMTh in the management of CNCP.

\section{Author Contributions}

Drs Rehman, Ferguson, Blair, Bozek, Alison, and Johnston provided substantial contributions to conception and design, acquisition of data, or analysis and interpretation of data; Drs Rehman, Ferguson, Blair, Bozek, Johnston drafted the article or revised it critically, provided expert advice for important intellectual content; all authors gave final approval of the version of the article to be published; and all authors agree to be accountable for all aspects of the work in ensuring that questions related to the accuracy or integrity of any part of the work are appropriately investigated and resolved. 


\section{References}

1. Schopflocher $D$, Taenzer $P$, Jovey $R$. The prevalence of chronic pain in Canada. Pain Res Manag. 2011;16(6):445-450. doi:10.1155/2011/ 876306

2. Dahlhamer J, Lucas J, Zelaya C, et al. Prevalence of Chronic Pain and High-Impact Chronic Pain Among Adults - United States, 2016. MMWR Morb Mortal Wkly Rep. 2018;67(36):1001-1006. doi:10.15585/ mmwr.mm6736a2

3. Reid KJ, Harker J, Bala MM, et al. Epidemiology of chronic non-cancer pain in Europe: narrative review of prevalence, pain treatments and pain impact. Curr Med Res Op. 2011;27(2):449-462. doi:10.1185/ 03007995.2010.545813

4. Blyth FM, Briggs AM, Schneider CH, Hoy DG, March LM. The Global Burden of Musculoskeletal Pain-Where to From Here? Am J Public Health. 2019;109(1):35-40. doi:10.2105/AJPH.2018.304747

5. Briggs $A M$, Woolf $A D$, Dreinhöfer $K$, et al. Reducing the global burden of musculoskeletal conditions. Bull World Health Organ. 2018;96 (5):366-368. doi:10.2471/BLT.17.204891

6. March L, Smith EUR, Hoy DG, et al. Burden of disability due to musculoskeletal (MSK) disorders. Best Pract Res Clin Rheumatol. 2014;28(3):353-366. doi:10.1016/j.berh.2014.08.002

7. Woolf AD. Global burden of osteoarthritis and musculoskeletal diseases. BMC Musculoskeletal Disorders. 2015;16(Suppl 1):S3-S3. doi:10.1186/1471-2474-16-S1-S3

8. Vargas C, Bilbeny N, Balmaceda C, et al. Costs and consequences of chronic pain due to musculoskeletal disorders from a health system perspective in Chile. Pain Rep. 2018;3(5):e656-e656. doi:10.1097/ PR9.0000000000000656

9. Peng $\mathrm{P}$, Choiniere $\mathrm{M}$, Dion $\mathrm{D}$, et al. Challenges in accessing multidisciplinary pain treatment facilities in Canada. Can J Anaesth. 2007;54(12):977. doi:10.1007/BF03016631

10. Bishop MD, Torres-Cueco R, Gay CW, Lluch-Girbés E, Beneci JM, Bialosky JE. What effect can manual therapy have on a patient's pain experience? Pain Manag. 2015;5(6):455-464. doi:10.2217/pmt.15.39

11. Turk DC, Wilson HD, Cahana A. Treatment of chronic non-cancer pain. Lancet. 2011;377(9784):2226-2235. doi:10.1016/S0140-6736 (11)60402-9

12. Bogduk N. Management of chronic low back pain. Med J Austr. 2004;180(2):79-83. doi:10.5694/j.1326-5377.2004.tb05805.x

13. Fawkes CA, Leach CMJ, Mathias S, Moore AP. A profile of osteopathic care in private practices in the United Kingdom: A national pilot using standardised data collection. Man Ther. 2014;19(2):125-130. doi:10.1016/j.math.2013.09.001

14. Burke SR, Myers R, Zhang AL. A profile of osteopathic practice in Australia 2010-2011: a cross sectional survey. BMC Musculoskeletal Disorders. 2013;14:227-227. doi:10.1186/1471-2474-14-227

15. Zügel M, Maganaris $\mathrm{CN}$, Wilke J, et al. Fascial tissue research in sports medicine: from molecules to tissue adaptation, injury and diagnostics: consensus statement. Br J Sports Med. 2018;52 (23):1497. doi:10.1136/bjsports-2018-099308

16. Rizkalla MN, Henderson KK, Huntington-Alfano K, et al. Does Osteopathic Manipulative Treatment Make a Neuropsychological Difference in Adults With Pain? A Rationale for a New Approach. J Am Osteopath Assoc. 2018;118(9):617-622. doi:10.7556/jaoa.2018.136
17. Degenhardt BF, Darmani NA, Johnson JC, et al. Role of Osteopathic Manipulative Treatment in Altering Pain Biomarkers: A Pilot Study. J Am Osteopath Assoc. 2007;107(9):387-400.

18. Picchiottino M, Leboeuf-Yde C, Gagey O, Hallman DM. The acute effects of joint manipulative techniques on markers of autonomic nervous system activity: a systematic review and meta-analysis of randomized sham-controlled trials. Chiropr Man Therap. 2019;27:17-17. doi:10.1186/s12998-019-0235-1

19. Draper BB, Johnson JC, Fossum C, Chamberlain NR. Osteopathic Medical Students' Beliefs About Osteopathic Manipulative Treatment at 4 Colleges of Osteopathic Medicine. J Am Osteopath Assoc. 2011;111(11):615-630.

20. Paulus $S$. The core principles of osteopathic philosophy. Int $J$ Osteopath Med. 2013;16(1):11-16. doi:10.1016/j.josm.2012.08.003

21. Rogers FJ, D'Alonzo GE Jr, Glover JC, et al. Proposed tenets of osteopathic medicine and principles for patient care. J Am Osteopath Assoc. 2002;102(2):63-65

22. Licciardone JC, Herron KM. Characteristics, satisfaction, and perceptions of patients receiving ambulatory healthcare from osteopathic physicians: a comparative national survey. J Am Osteopath Assoc. 2001;101(7):374-385.

23. Adams J, Sibbritt D, Steel A, Peng W. A workforce survey of Australian osteopathy: analysis of a nationally-representative sample of osteopaths from the Osteopathy Research and Innovation Network (ORION) project. BMC Health Serv Res. 2018;18(1):352-352. doi:10.1186/s12913-018-3158-y

24. Alvarez Bustins G, López Plaza P-V, Carvajal SR. Profile of osteopathic practice in Spain: results from a standardized data collection study. BMC Complementary and Alternative Medicine. 2018;18(1):129. doi:10.1186/s12906-018-2190-0

25. Orrock PJ, Myers SP. Osteopathic intervention in chronic non-specific low back pain: a systematic review. BMC Musculoskeletal Disorders. 2013;14(1):129. doi:10.1186/1471-2474-14-129

26. Verhaeghe N, Schepers J, van Dun P, Annemans L. Osteopathic care for spinal complaints: A systematic literature review. PLoS One. 2018;13(11):e0206284. doi:10.1371/journal.pone.0206284

27. Saracutu M, Rance J, Davies H, Edwards DJ. The effects of osteopathic treatment on psychosocial factors in people with persistent pain: A systematic review. Int J Osteopath Med. 2018;27:23-33. doi:10.1016/j.ijosm.2017.10.005

28. Franke H, Franke JD, Fryer G. Osteopathic manipulative treatment for chronic nonspecific neck pain: A systematic review and meta-analysis Int J Osteopath Med. 2015;18(4):255-267. doi:10.1016/j. ijosm.2015.05.003

29. Franke H, Franke JD, Fryer G. Osteopathic manipulative treatment fo nonspecific low back pain: a systematic review and meta-analysis. BMC Musculoskeletal Disorders. 2014;15:286-286. doi:10.1186/ 1471-2474-15-286

30. Licciardone JC, Brimhall AK, King LN. Osteopathic manipulative treatment for low back pain: a systematic review and meta-analysis of randomized controlled trials. BMC Musculoskelet Disorders. 2005;6:43. doi:10.1186/1471-2474-6-43

31. Guyatt $G H$, Oxman $A D$, Kunz R, Vist GE, Falck-Ytter $Y$, Schünemann HJ. What is "quality of evidence" and why is it important to clinicians? BMJ. 2008;336(7651):995. doi: 10.1136/ bmj.39490.551019.BE 
32. Guyatt GH, Oxman AD, Vist GE, et al. GRADE: an emerging consensus on rating quality of evidence and strength of recommendations. BMJ. 2008;336(7650):924. doi:10.1136/ bmj.39489.470347.AD

33. Liberati A, Altman DG, Tetzlaff J, et al. The PRISMA statement for reporting systematic reviews and meta-analyses of studies that evaluate healthcare interventions: explanation and elaboration. BMJ. 2009;339:b2700. doi:10.1136/bmj.b2700

34. Moore RA, Derry S, Wiffen P.J. Challenges in design and interpretation of chronic pain trials. Br J Anaesth. 2013;111(1):38-45. doi:10.1093/bja/aet126

35. Higgins JPT, Green S, eds. Cochrane Handbook for Systematic Reviews of Interventions. Wiley-Blackwell; 2008.

36. Karlsson P, Bergmark A. Compared with what? An analysis of control-group types in Cochrane and Campbell reviews of psychosocial treatment efficacy with substance use disorders. Addiction. 2015;110(3):420-428. doi:10.1111/add.12799

37. Albers J, Jakel A, Wellmann K, von Hehn U, Schmidt T. Effectiveness of 2 Osteopathic Treatment Approaches on Pain, Pressure-Pain Threshold, and Disease Severity in Patients with Fibromyalgia: A Randomized Controlled Trial. Complement Med Res. 2018;25 (2):122-128. doi:10.1159/000464343

38. Licciardone JC, Stoll ST, Fulda KG, et al. Osteopathic Manipulative Treatment for Chronic Low Back Pain: A Randomized Controlled Trial. Spine. 2003;28(13):1355-1362. doi:10.1097/01. BRS.0000067110.61471.7D

39. Stepnik J, Czaprowski D. Assessment of the effects of manual techniques on neck pain. Postepy Rehabilitacji. 2018;32:33-39. doi:10.5114/areh.2018.77935

40. Schwerla F, Bischoff A, Nurnberger A, Genter P, Guillaume JP, Resch $\mathrm{KL}$. Osteopathic treatment of patients with chronic non-specific neck pain: a randomised controlled trial of efficacy. Forsch Komplementmed. 2008;15(3):138-145. doi:10.1159/000132397

41. Altinbilek T, Murat S, Yumusakhuylu Y, Icagasioglu A. Osteopathic manipulative treatment improves function and relieves pain in knee osteoarthritis: A single-blind, randomized-controlled trial. Turk J Phys Med Rehabil. 2018;64(2):114-120. doi:10.5606/tttrd.2018.1384

42. Knebl J, Shores J, Gamber R, Gray W, Herron K. Improving functional ability in the elderly via the Spencer technique, an osteopathic manipulative treatment: A randomized, controlled trial. J Am Osteopath Assoc. 2002;102:387-396.

43. Cuccia AM, Caradonna C, Annunziata V, Caradonna D. Osteopathic manual therapy versus conventional conservative therapy in the treatment of temporomandibular disorders: a randomized controlled trial. J Bodyw Mov Ther. 2010;14(2):179-184. doi:10.1016/j.jbmt.2009.08.002

44. Marske C, Bernard N, Palacios A, et al. Fibromyalgia with Gabapentin and Osteopathic Manipulative Medicine: A Pilot Study. J Altern Complement Med. 2018;24(4):395-402. doi:10.1089/acm.2017.0178

45. Papa L, Mandara A, Bottali M, Gulisano V, Orfei S. A randomised control trial on the effectiveness of osteopathic manipulative treatment in reducing pain and improving the quality of life in elderly patients affected by osteoporosis. Clin Cases Min Bone Metab. 2012;9:179-183.

46. Silva ACO, Biasotto-Gonzalez DA, Oliveira FHM, et al. Effect of Osteopathic Visceral Manipulation on Pain, Cervical Range of Motion, and Upper Trapezius Muscle Activity in Patients with Chronic Nonspecific Neck Pain and Functional Dyspepsia: A Randomized, Double-Blind, Placebo-Controlled Pilot Study. Evid Based Complement Alternat Med. 2018;2018:4929271. doi:10.1155/2018/ 4929271

47. Tamer S, Öz M, Ülger Ö. The effect of visceral osteopathic manual therapy applications on pain, quality of life and function in patients with chronic nonspecific low back pain. J Back Musculoskelet Rehabil. 2017;30(3):419-425. doi:10.3233/BMR-150424

48. Marti-Salvador M, Hidalgo-Moreno L, Domenech-Fernandez J, Lison JF, Arguisuelas MD. Osteopathic Manipulative Treatment Including Specific Diaphragm Techniques Improves Pain and Disability in Chronic Nonspecific Low Back Pain: A Randomized Trial. Arch Phys Med Rehabil. 2018;99(9):1720-1729. doi:10.1016/j. apmr.2018.04.022

49. Burton AK, Tillotson K, Cleary J. Single-blind randomised controlled trial of chemonucleolysis and manipulation in the treatment of symptomatic lumbar disc herniation. Eur Spine J. 2000;9:202-207. doi:10.1007/s005869900113

50. Licciardone JC, Minotti DE, Gatchel RJ, Kearns CM, Singh KP. Osteopathic manual treatment and ultrasound therapy for chronic low back pain: a randomized controlled trial. Ann Fam Med. 2013;11 (2):122-129. doi:10.1370/afm.1468

51. Vismara L, Cimolin V, Menegoni F, et al. Osteopathic manipulative treatment in obese patients with chronic low back pain: a pilot study. Man Ther. 2012;17(5):451-455. doi:10.1016/j.math.2012.05.002

52. Chown M, Whittamore L, Rush M, Allan S, Stott D, Archer M. A prospective study of patients with chronic back pain randomised to group exercise, physiotherapy or osteopathy. Physiotherapy. 2008;94 (1):21-28. doi:10.1016/j.physio.2007.04.014

53. Faber J, Fonseca LM. How sample size influences research outcomes. Dental Press J Orthod. 2014;19(4):27-29. doi:10.1590/ 2176-9451.19.4.027-029.ebo

54. McNeish D, Stapleton L. The Effect of Small Sample Size on Two Level Model Estimates: A Review and Illustration. Educ Psychol Rev. 2016;28. doi:10.1007/s10648-014-9287-x

55. Schmucker CM, Blümle A, Schell LK, et al. Systematic review finds that study data not published in full text articles have unclear impact on meta-analyses results in medical research. PloS One. 2017;12(4):e0176210-e0176210. doi:10.1371/journal. pone. 0176210

56. Hartling L, Ospina M, Liang $\mathrm{Y}$, et al. Risk of bias versus quality assessment of randomised controlled trials: cross sectional study. BMJ. 2009;339:b4012. doi:10.1136/bmj.b4012

57. Savović J, Turner R, Mawdsley D, et al. Association Between Risk-of-Bias Assessments and Results of Randomized Trials in Cochrane Reviews: The ROBES Meta-Epidemiologic Study. Am J Epidemiol. 2017;187. doi:10.1093/aje/kw×344

58. Rubinstein SM, de Zoete A, van Middelkoop M, Assendelft WJJ, de Boer MR, van Tulder MW. Benefits and harms of spinal manipulative therapy for the treatment of chronic low back pain: systematic review and meta-analysis of randomised controlled trials. BMJ. 2019;364: 1689. doi:10.1136/bmj.1689

59. Hidalgo B, Detrembleur C, Hall T, Mahaudens P, Nielens H. The efficacy of manual therapy and exercise for different stages of 
non-specific low back pain: an update of systematic reviews. $J$ Man Manip Ther. 2014;22(2):59-74. doi:10.1179/2042618613Y.0000000041

60. Posadzki P, Ernst E. Osteopathy for musculoskeletal pain patients: a systematic review of randomized controlled trials. Clin Rheumatol. 2011;30(2):285-291. doi:10.1007/s10067-010-1600-6

61. Wang L, Hong BY, Kennedy SA, et al. Predictors of Unemployment After Breast Cancer Surgery: A Systematic Review and Meta-Analysis of Observational Studies. J Clin Oncol. 2018;36(18):1868-1879. doi:10.1200/JCO.2017.77.3663

62. Barr AE, Barbe MF. Pathophysiological tissue changes associated with repetitive movement: a review of the evidence. Phys Ther. 2002;82(2):173-187. doi:10.1093/ptj/82.2.173

63. Fine PG. Long-Term Consequences of Chronic Pain: Mounting Evidence for Pain as a Neurological Disease and Parallels with Other
Chronic Disease States. Pain Med. 2011;12(7):996-1004. doi:10.1111/ j.1526-4637.2011.01187.x

64. Chila A, American Osteopathic Association. Foundations of Osteopathic Medicine. 2nd ed: Philadelphia : Wolters Kluwer Health/ Lippincott Williams \& Wilkins; 2011.

65. Panagopoulos J, Hancock M, Ferreira P. Does the addition of visceral manipulation improve outcomes for patients with low back pain? Rationale and study protocol. J Bodyw Mov Ther. 2013;17(3):339-343. doi:10.1016/j.jbmt.2012.12.004

66. Attali TV, Bouchoucha M, Benamouzig R. Treatment of refractory irritable bowel syndrome with visceral osteopathy: short-term and long-term results of a randomized trial. J Dig Dis. 2013;14 (12):654-661. doi:10.1111/1751-2980.12098

@ 2020 American Osteopathic Association 